\title{
Heavy metal contamination of surface soils in southern part of Bangladesh
}

\author{
Shaikh Abdul Latif ${ }^{1,2 *}$, Shahrin Sharif ${ }^{3}$, Syed Mohammod Hossain ${ }^{2}$, Mohammad Amirul Islam², Ibrahim Mustafa \\ Mehedi ${ }^{4}$ and Mahfusa Sharifa Sultana ${ }^{3}$ \\ ${ }^{1}$ Faculty of Engineering, King Abdulaziz University, P.O. Box No.: 80204, Jeddah - 21589, \\ Kingdom of Saudi Arabia \\ ${ }^{2}$ Institute of Nuclear Science and Technology, Atomic Energy Research Establishment, Savar, \\ GPO Box No.: 3787, Dhaka-1000, Bangladesh \\ ${ }^{3}$ Department of Environmental Science, Jahangirnagar University, Savar, Dhaka, Bangladesh \\ ${ }^{4}$ Center of Excellence in Intelligent Engineering Systems (CEIES), Department of Electrical and \\ Computer Engineering, King Abdulaziz University, Jeddah - 21589, Saudi Arabia
}

\begin{abstract}
To assess contamination levels of the heavy metals, concentrations of $\mathrm{Sc}, \mathrm{Cr}, \mathrm{Fe}$, Co and $\mathrm{Zn}$ in surface soils at various locations of southern part of Bangladesh were determined by Instrumental Neutron Activation Analysis (INAA) technique. In this study, concentrations of the $\mathrm{Sc}, \mathrm{Cr}, \mathrm{Fe}$, Co and Zn elements in surface soil were found in the range of 2.56-16.7 $\mu \mathrm{g} / \mathrm{g}, 12.9-112 \mu \mathrm{g} / \mathrm{g}, 6911-48642 \mu \mathrm{g} / \mathrm{g}, 2.59-22.7 \mu \mathrm{g} / \mathrm{g}$ and 37.7-322 $\mu \mathrm{g} / \mathrm{g}$, respectively. The measured concentrations were compared with average concentration of worldwide soil and observed that most of the samples contain much higher concentration of heavy metals except $\mathrm{Cr}$ and Fe. Analysis based on soil utilization type showed that the samples collected from roadside and residential area experienced much higher metal contamination than open area. A significant correlation was observed between $\mathrm{Cr}$ - $\mathrm{Fe}, \mathrm{Cr}$ - $\mathrm{Co}, \mathrm{Cr}$-Sc, $\mathrm{Fe}$ - $\mathrm{Co}, \mathrm{Fe}-\mathrm{Sc}$ and $\mathrm{Co}-\mathrm{Sc}$.
\end{abstract}

Keywords: Metal contamination, surface soil, INAA, research reactor, Bangladesh

\section{Introduction}

Soil is a vital component of the biosphere. It is known as a geochemical sink for contaminants, and it also transports the chemical elements and substances to the various stages of biosphere (atmosphere, hydrosphere, and biota) as a natural buffer (Kabata-Pendias and Pendias, 2001; Wu et al., 2015; Kumar et al., 2019). Recently due to the human activities, natural balance of biogeochemical cycles is significantly altered. It elevates the mobilization of chemical elements into the atmosphere in contrast to the natural process. Therefore, the important processes may become potentially harmful under natural condition. The soil has an absorption capacity to hold and accumulate trace metal to some extent. Migration can be started significantly by changing the condition that controls the mobility of adsorbed metals (Salmons and Frostner, 1995; Harfouche et al., 2016; Lian et al., 2019). The perseverance of contaminants in soil is much higher compared to other compartments of the biosphere and contamination of soil caused by trace elements. Thus, the contamination of soil seems to be virtually permanent. So, it is the responsibility of the mankind to maintain the ecological and agricultural functions of the soil (Kabata-Pendias and Pendias, 2001). The regional contamination of soils due to heavy metals occurs mainly in industrial areas (factories, smelter, motor vehicles, and municipal wastes dumping sites) (Krishna and Govil, 2007; Mandal and Sengupta, 2006; Li et al., 2015). Moreover, the soil can be contaminated by other sources of metal pollutants, pesticides, fertilizers and materials derived by sewage and these are added as the trace element pool in soils. Soil contamination in some industrial areas can be occurred by an important source like mobilization of windblown dust. Heavy metals are being deliberately used by industrialized and non-industrialized countries for their industrial, agricultural, and domestic purposes without any treatment of remnant metals in prior. As a result, the environment is being elevated due to the deposition of heavy metals (Salmons and Frostner, 1995).

Khalishpur Thana is one of the industrial areas in Khulna district of Bangladesh. A study by World Bank identified the spatial distribution of the most polluted six 'hot spots' in Bangladesh and Khulna is one of them. There are many large industries (steel manufacturing, ship building industry, cable industries, jute mills, hardboard mills, pipe factories etc.) located in the southern region especially in Khalishpur Thana. These industries produce a considerable amount of solid wastes and effluents, which spread over the adjacent farmland, water body and to

*Email: sklatif1967@gmail.com 
immediate locality. The saline characteristics of water and soil in this region also influence the accumulation of heavy metals that in turn may be harmful for indigenous flora and fauna.

In general, the hazardous contaminants spread into the environment through various media such as soil, mineral, water and vegetation from industrial area. The human body is being affected by several diseases due to the accumulation of these hazardous contaminants while it passes through the food chain. It is essential to create the base line data for the toxic elements and radionuclides in the contaminated area of industrial zone in order to save the population and to take the remedial action (Sultana et al., 2003; Latif et al., 2009; Islam et al., 2011; Khademi et al., 2019). However, a limited number of research works are found in Bangladesh due to lack of sophisticated techniques and appropriate facilities for the assessment of natural radionuclides and heavy metals in the environmental matrices.
Multi-elements can be determined in a broad range of matrices by the most powerful non-destructive neutron activation analysis technique. Instrumental neutron activation analysis (INAA) is one of the most extensively used methods for determination of elemental concentration due to its high sensitivity, precision, versatility and multielemental character (Greenberg et al., 2011; Tamim et al., 2016; Islam et al., 2017). Particularly INAA is the most suitable for solid matrices, e.g. soil, because no digestion is needed in this technique. For these reasons, the NAA technique is the best among the methods- Inductively Coupled Plasma Mass Spectrometry (ICP-MS), X-ray Fluorescence (XRF), Atomic Absorption Spectrometry (AAS), etc. (Ehmann and Diane, 1991). In view of the above considerations, the present work was undertaken to study the contaminations of heavy metals in surface soils around the industrial area of Khalishpur Thana in Khulna, Bangladesh using INAA.

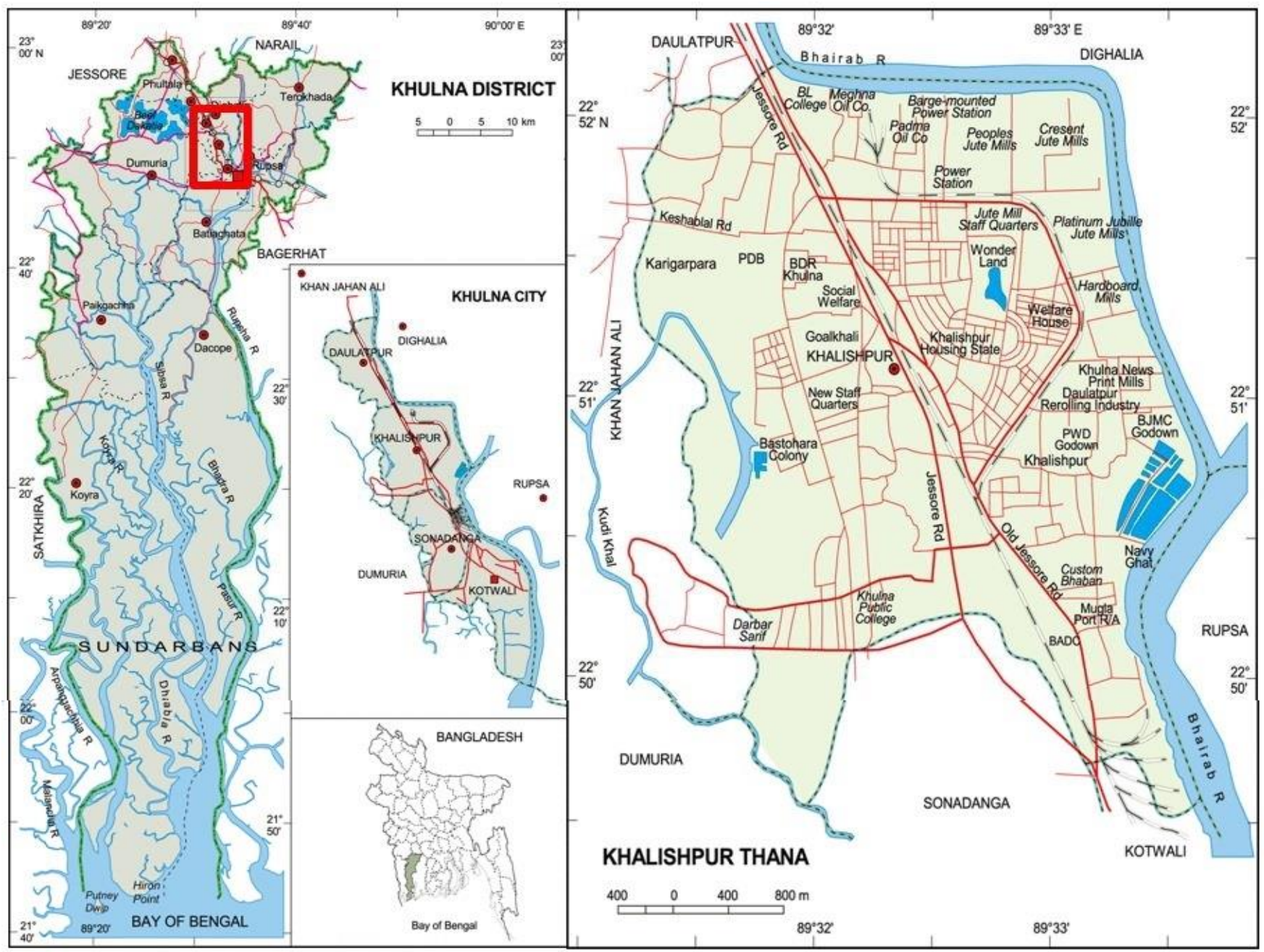

Fig. 1: Geographical location of the study area 


\section{Materials and Methods}

The soil samples were collected randomly from various sites of Khalishpur industrial area $\left(89^{\circ} 30^{\prime}\right.$ to $89^{\circ} 35^{\prime} \mathrm{E}$ and $22^{\circ} 47^{\prime}$ to $22^{\circ} 55^{\prime} \mathrm{N}$ ), Khulna, Bangladesh. The geographical location of the sampling area is shown in Fig. 1. In this study the sampling sites were selected in the uncultivated areas assuming that the pollution arises only from the atmospheric deposition not from other sources like utilization of fertilizer or irrigation. Twenty-six surface soil samples (from $0-10 \mathrm{~cm}$ ) were taken from the high lands mainly from the open areas, roadsides and residential areas of Khalishpur Thana in Khulna district at $26^{\text {th }}$ May 2007. An oven was used for drying the samples at a temperature of about $70^{\circ} \mathrm{C}$ until they attained constant weight. An agate mortar was used to make powder samples from the dried soils for ensuring the homogeneity. About $50 \mathrm{mg}$ of each sample was packed into a polyethylene bag. IAEA certified reference materials (CRM) e.g. soil-7 and SL-1 were also packed in a clean small polyethylene bag. The soil sample were doubly heat sealed by polyethylene bags. The samples and standards were placed in a vial for irradiation.

In the present study 3MW TRIGA Mark-II research reactor of Bangladesh Atomic Energy Commission was applied for the irradiation purposes of both soil samples and standards. The IAEA Soil-7 \& SL-1 were used as standards in this work. The samples and standards were irradiated with neutron flux about $1.52 \times 10^{13} \mathrm{n} / \mathrm{cm}^{2} / \mathrm{s}$ for 40 minutes at 250 $\mathrm{kW}$ in Dry Central Thimble (DCT) of 3MW TRIGA Mark-II research reactor. To check the variation of neutron flux three iron $(\mathrm{Fe})$ foils were irradiated along the stacked samples simultaneously at bottom, middle and top of stack samples. High Purity Germanium (HPGe) gamma-ray spectrometry system and gamma-ray acquisition software were used for the measurement of the activities of the irradiated samples. The irradiated samples were allowed for two days decay to reduce the high activity before start radioactivity measurement. To avoid radioactive contamination the outer envelopes of irradiated samples were replaced by new polyethylene bags before radioactive counting. The geometry was same for both samples and standards gamma-ray spectra measurements. Normally the dead time was maintained below $10 \%$ and the uncertainty of peak area was less than 5\% during radioactive counting. To avoid the interference of overlapping gammalines from undesired radioactive nuclides sufficient cooling time was allowed between each sample radioactivity measurement. In this study each sample was counted three times.

\section{Results and Discussion}

The concentrations of the elements $\mathrm{Sc}, \mathrm{Cr}, \mathrm{Fe}, \mathrm{Co}$ and $\mathrm{Zn}$ in surface soils of Khulna, which is in the southern part of Bangladesh, were determined by relative method using INAA. The $\mathrm{Sc}, \mathrm{Cr}, \mathrm{Fe}, \mathrm{Co}$ and $\mathrm{Zn}$ elements of soils were identified with the gamma-ray energies from the decay of the ${ }^{46} \mathrm{Sc},{ }^{51} \mathrm{Cr},{ }^{59} \mathrm{Fe},{ }^{60} \mathrm{Co}$ and ${ }^{65} \mathrm{Zn}$ radionuclides, respectively, which were produced via $(n, \gamma)$ reaction on the corresponding target isotopes. The decay characteristics of the above radionuclides are quoted in Table 1. The detection limits $(3 \sigma)$ determined under the present experimental conditions for $\mathrm{Sc}, \mathrm{Cr}, \mathrm{Fe}, \mathrm{Co}$ and $\mathrm{Zn}$ were 0.29 $\mu \mathrm{g} / \mathrm{g}, \quad 1.0 \mu \mathrm{g} / \mathrm{g}, \quad 147 \mu \mathrm{g} / \mathrm{g}, \quad 0.61 \mu \mathrm{g} / \mathrm{g}$ and $11.37 \mu \mathrm{g} / \mathrm{g}$, respectively. To investigate the reliability of the analysis of the data quality assurance (QA) test was performed by measuring $\mathrm{Sc}, \mathrm{Cr}, \mathrm{Fe}$ and $\mathrm{Zn}$ concentration level in certified reference materials Soil-7 relative to another certified

Table 1: The investigated elements, product nuclides and their decay characteristics

\begin{tabular}{ccccc}
\hline Element & Reaction & Half-life & $\begin{array}{c}\text { Gamma-ray energy } \\
(\mathbf{k e V})\end{array}$ & $\begin{array}{c}\text { Branching ratio } \\
(\boldsymbol{\%})\end{array}$ \\
\hline $\mathrm{Sc}$ & ${ }^{45} \mathrm{Sc}(\mathrm{n}, \gamma)^{46} \mathrm{Sc}$ & $83.8 \mathrm{~d}$ & 889.3 & 100 \\
$\mathrm{Cr}$ & ${ }^{50} \mathrm{Cr}(\mathrm{n}, \gamma)^{51} \mathrm{Cr}$ & $27.71 \mathrm{~d}$ & 320 & 9.8 \\
$\mathrm{Fe}$ & ${ }^{58} \mathrm{Fe}(\mathrm{n}, \gamma)^{59} \mathrm{Fe}$ & $44.6 \mathrm{~d}$ & 1099 & 56 \\
$\mathrm{Co}$ & ${ }^{59} \mathrm{Co}(\mathrm{n}, \gamma)^{60} \mathrm{Co}$ & $5.272 \mathrm{y}$ & 1173.2 & 99.9 \\
& & & 1332.5 & 100 \\
$\mathrm{Zn}$ & ${ }^{64} \mathrm{Zn}(\mathrm{n}, \gamma)^{65} \mathrm{Zn}$ & $243.7 \mathrm{~d}$ & 1115.5 & 49.8 \\
\hline
\end{tabular}

Table 2: Comparison of elemental concentrations $(\mu \mathrm{g} / \mathrm{g})$ determined in this study with certified values of the IAEA-CRM-Soil-7

\begin{tabular}{cccc}
\hline Element & This study & Certified value & Deviation $^{\text {a }}(\%)$ \\
\hline Sc & 8.83 & 8.3 & 6.00 \\
Cr & 105.56 & 104.00 & 1.48 \\
Fe & 25060 & 25700 & 2.35 \\
Zn & 112.97 & 104.00 & 7.94 \\
\hline
\end{tabular}

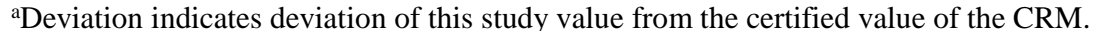


reference materials SL-1. The analytical results for the certified reference materials are given in Table 2. The experimental results had 1-8 \% deviations from the
$16.7 \mu \mathrm{g} / \mathrm{g}, 12.9-112 \mu \mathrm{g} / \mathrm{g}, 6911-48642 \mu \mathrm{g} / \mathrm{g}, 2.59-22.7 \mu \mathrm{g} / \mathrm{g}$ and 37.7-322 $\mu \mathrm{g} / \mathrm{g}$, respectively (Table 3 ). The highest mean concentration was observed $37981 \mu \mathrm{g} / \mathrm{g}$ for Fe. The lowest

Table 3: Measured elemental concentrations $(\mu \mathrm{g} / \mathrm{g})$ of the investigated elements in soil

\begin{tabular}{|c|c|c|c|c|c|c|}
\hline \multirow[t]{2}{*}{ Soil utilization pattern } & \multirow[t]{2}{*}{ Location } & \multicolumn{3}{|c|}{ Elements } & \multirow[b]{2}{*}{ Co } & \multirow[b]{2}{*}{ Sc } \\
\hline & & $\mathrm{Cr}$ & $\mathbf{Z n}$ & $\mathbf{F e}$ & & \\
\hline \multirow[t]{12}{*}{ Open area } & Kashipur & 47.7 & 153 & 22367 & 9.33 & 6.75 \\
\hline & Karigarpara & 62.2 & 160 & 29887 & 14.4 & 10.7 \\
\hline & Cresent jute mill & 66.3 & 92.7 & 26414 & 8.66 & 7.45 \\
\hline & Mujgunni (Mollapara) & 42.7 & 167 & 18307 & 9.82 & 6.49 \\
\hline & Goalkhali & 62.9 & 162 & 28475 & 14.5 & 10.6 \\
\hline & Khalishpur & 12.9 & 37.7 & 6911 & 2.59 & 2.56 \\
\hline & Hard board mill & 52.8 & 49.0 & 22538 & 6.28 & 5.73 \\
\hline & Boyra & 51.8 & 140 & 20055 & 10.4 & 5.87 \\
\hline & Range & $12.9-66.3$ & \multicolumn{2}{|c|}{$37.7-1676911-29887$} & $2.59-14.5$ & $2.56-10.7$ \\
\hline & Average & 49.9 & 120 & 21869 & 9.50 & 7.02 \\
\hline & STD & 17.0 & 53.1 & 7260 & 3.94 & 2.67 \\
\hline & Coefficient of variation & 0.341 & 0.441 & 0.332 & 0.415 & 0.380 \\
\hline \multirow{15}{*}{ Road side } & Kashipur & 71.2 & 231 & 32009 & 15.5 & 11.6 \\
\hline & Karigarpara & 86.8 & 171 & 43873 & 19.1 & 15.1 \\
\hline & Pabla & 96.1 & 156 & 45955 & 22.7 & 15.9 \\
\hline & Peoples jute mill & 105 & 186 & 48642 & 19.2 & 14.6 \\
\hline & Mujgunni & 48.7 & 176 & 22153 & 11.4 & 6.66 \\
\hline & Goalkhali & 78.0 & 179 & 37524 & 16.5 & 13.7 \\
\hline & Khalishpur & 100 & 107 & 46991 & 18.8 & 16.8 \\
\hline & Khalishpur & 76.0 & 89.4 & 37437 & 14.4 & 12.7 \\
\hline & Newsprint mill & 65.3 & 322 & 33440 & 9.11 & 6.45 \\
\hline & Boyra (Raermahal) & 78.1 & 146 & 44015 & 19.7 & 15.4 \\
\hline & Moddhopara & 64.1 & 322 & 25749 & 10.5 & 9.00 \\
\hline & Range & $48.7-105$ & $89.4-322$ & $22153-48642$ & $9.11-22.7$ & $6.45-16.7$ \\
\hline & Average & 79.1 & 189.6 & 37980.7 & 16.1 & 12.5 \\
\hline & STD & 17.0 & 75.7 & 8868 & 4.33 & 3.66 \\
\hline & Coefficient of variation & 0.215 & 0.400 & 0.233 & 0.270 & 0.292 \\
\hline \multirow{11}{*}{ Residential area } & Karigarpara & 65.4 & 152 & 29574 & 13.5 & 11.0 \\
\hline & Pabla (Shahapara) & 96.1 & 156 & 45955 & 22.7 & 15.9 \\
\hline & Mujguni (Dakhinparar) & 47.8 & 144 & 21401 & 10.7 & 7.36 \\
\hline & GoalKhali & 89.1 & 160 & 47702 & 18.9 & 15.6 \\
\hline & Charerhat & 112 & 83.3 & 48131 & 19.0 & 16.4 \\
\hline & Boyra & 54.4 & 134 & 22568 & 11.6 & 6.41 \\
\hline & Gabtala & 35.6 & 92.3 & 16485 & 5.71 & 5.35 \\
\hline & Range & $35.6-112$ & $83.3-160$ & $16485-48131$ & $5.71-22.7$ & $5.35-16.4$ \\
\hline & Average & 71.5 & 132 & 33117 & 14.6 & 11.1 \\
\hline & STD & 28.1 & 31.3 & 13788 & 5.89 & 4.83 \\
\hline & Coefficient of variation & 0.393 & 0.237 & 0.416 & 0.404 & 0.434 \\
\hline
\end{tabular}

$\mathrm{STD}=$ standard deviation $(1 \sigma)$

corresponding certified values of the CRM.

The concentration range, average, standard deviation and coefficient of variation for the soil samples are given in Table 3. The concentrations of the $\mathrm{Sc}, \mathrm{Cr}, \mathrm{Fe}, \mathrm{Co}$ and $\mathrm{Zn}$ elements in surface soil were found in the range of 2.56- mean concentration was observed $7.02 \mu \mathrm{g} / \mathrm{g}$ for Sc. As shown in Fig. 2 comparing with the average metal concentration of worldwide soil (Bowen, 1979) it is found that most of the samples contain much higher concentration of heavy metals except $\mathrm{Cr}$ and $\mathrm{Fe}$. The exception may be 
due to the mobility of $\mathrm{Cr} . \mathrm{P}^{\mathrm{H}}$ of the soil governs the mobility of Cr. Very acidic media is suitable for its mobility. On the other hand, Fe can be substituted by many other metals such as $\mathrm{Co}, \mathrm{Sc}, \mathrm{Al}, \mathrm{Pb}$ etc. (Kabata-Pendias and Pendias, 2001). The average upper continental crystal (UCC) average values of Sc, Cr, Fe, Co and $\mathrm{Zn}$ are 14, 92, 39200, 17.3 and 67 $\mu \mathrm{g} / \mathrm{g}$, respectively, (Rudnick and Gao, 2014). If we compare our metal concentration values with UCC, it is observed that $\mathrm{Zn}$ concentrations in most of the soil samples are higher than the UCC values, especially in the samples from road

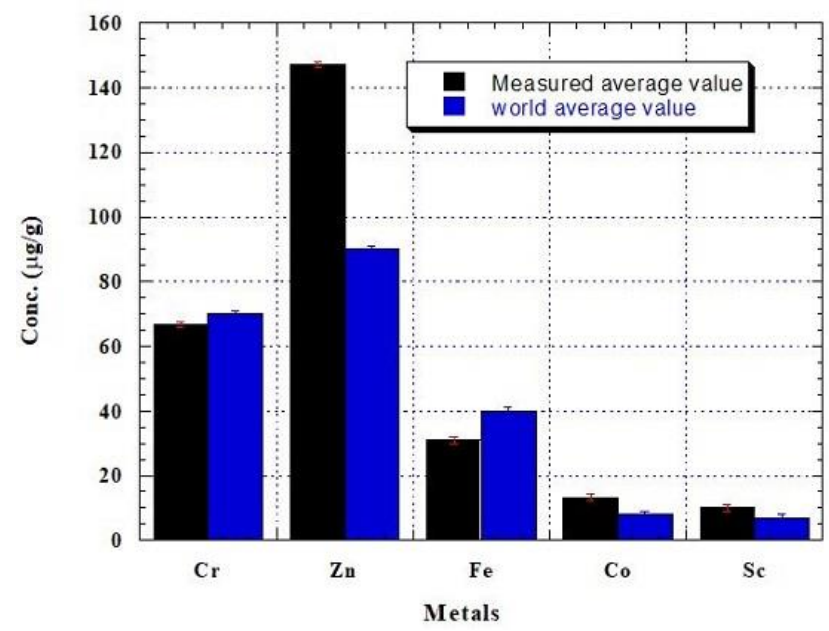

side areas.

Fig. 2: Comparison of the average metal concentration in the studied soil samples with the worldwide average value. (Fe concentration values are divided by 1000 ).

In the present study, it was found that the concentration of metal in surface soil varies with the soil utilization pattern. Most of the samples collected from road side area contain elevated concentration of heavy metals (Table 3). Average concentrations of the $\mathrm{Sc}, \mathrm{Cr}, \mathrm{Fe}, \mathrm{Co}$ and $\mathrm{Zn}$ elements in soil are much higher in road side and residential area than open area as given in Table 3. The reason of high concentration of $\mathrm{Zn}$ might be mainly due to the industrial activities, traffic densities, activities of roadside artisans, brake wires and radiators wear of studded tires, such as battery charging, vehicle repairs, iron bending, vehicle painting, panel beating, and atmospheric deposition. The concentration of $\mathrm{Zn}$ balance in surface soils of various ecosystems illustrates that the atmospheric input of this metal exceeds its output due to both leaching and the production of biomass (Krishna and Govil, 2004; Yarlagadda and Matsumoto, 1995). Other sources of Zn might be emission of zinc oxides from automobiles, brake linings, road salt, metal corrosion etc. Major sources of Sc are the combustion of coal and oil. Sources of Sc due to industrial activities are very limited. Scandium can substitute for $\mathrm{Fe}^{+3}$ (Kabata-Pendias and Pendias, 2001). So

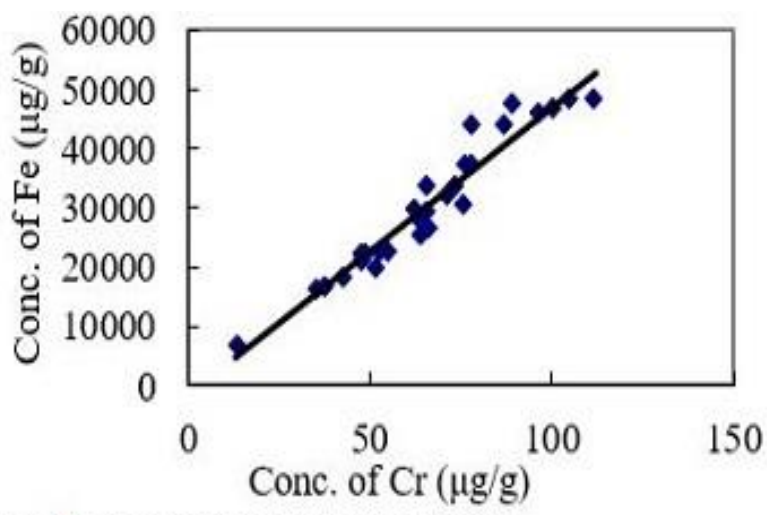

Fig. 3: Correlation between $\mathrm{Cr}$-Fe

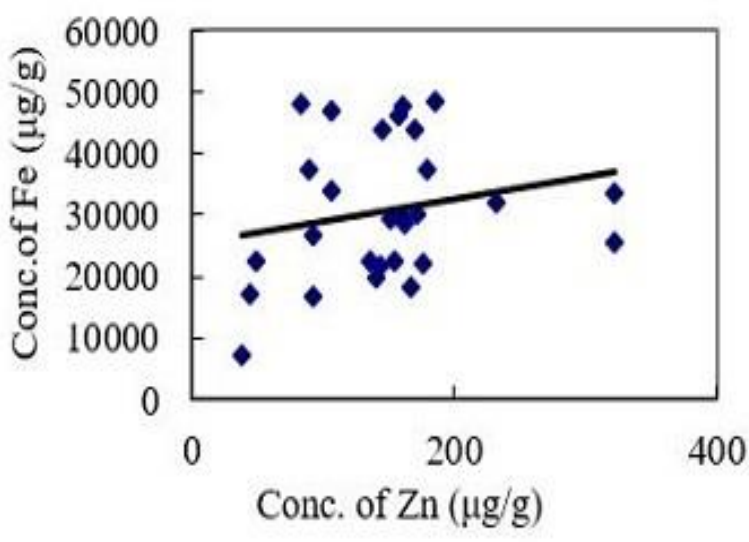

Fig. 4: Correlation between $\mathrm{Zn}-\mathrm{Fe}$

naturally soil contained higher concentration of Fe may contain elevated concentration of Sc.

It was observed that the heavy metals are most closely associated with each other. Strong positive correlation values were observed for $\mathrm{Cr}-\mathrm{Fe}$ (Fig. 3), $\mathrm{Cr}-\mathrm{Co}, \mathrm{Cr}-\mathrm{Sc}, \mathrm{Fe}-$ $\mathrm{Co}, \mathrm{Fe}-\mathrm{Sc}$, and $\mathrm{Co}-\mathrm{Sc}$ with corresponding values of 0.97 , $0.87,0.92,0.92,0.95$ and 0.95 . These results indicate that the accumulation patterns of $\mathrm{Cr}, \mathrm{Fe}$, $\mathrm{Co}$ and $\mathrm{Sc}$ in soils are correlated with one another to a significant extent. Fe and Co are included subgroup VIII in periodic table with very similar behaviors and due to the small differences in atomic radius; they are likely to form a wide range of mixed crystals. In general, $\mathrm{Cr}^{+3} \mathrm{Co}^{+3}, \mathrm{Sc}^{+3}$ resembles $\mathrm{Fe}^{+3}$ and also substitutes $\mathrm{Fe}^{+3}$ in various minerals. Very week correlation was found between $\mathrm{Zn}-\mathrm{Cr}, \mathrm{Zn}-\mathrm{Fe}$ (Fig. 4), Zn-Co, Zn-Sc with the corresponding values of $0.21,0.21,0.22,0.12$. Zn$\mathrm{Fe}$ antagonism is widely known, and an excess of $\mathrm{Zn}$ leads to a marked reduction in $\mathrm{Fe}$ concentration. There are two possible mechanisms of this interaction- the competition 
between $\mathrm{Zn}^{+2}$ and $\mathrm{Fe}^{+2}$ and the interference in chelating processes. In oxidizing, the mobility of $\mathrm{Zn}$ is high at neutral or alkaline condition. But the mobility of $\mathrm{Sc}, \mathrm{Cr}, \mathrm{Fe}$ and $\mathrm{Co}$ is very low in such conditions and strongly bound to soil organic matter (Kabata-Pendias and Pendias, 2001).

\section{Conclusions}

In the present study, concentration of $\mathrm{Sc}, \mathrm{Cr}, \mathrm{Fe}, \mathrm{Co}$ and $\mathrm{Zn}$ were assessed in surface soils of Khalishpur Thana. INAA method was used for the analysis of soil samples and it was found to be very sensitive method. The quality control tests indicate the reliability of the analysis. From the experiment this can be concluded that the average concentrations of heavy metals in the studied area are much higher than the average concentration of worldwide soil except $\mathrm{Cr}$ and $\mathrm{Fe}$. Analysis based on soil utilization type shows that samples collected from roadside and residential areas experience much higher metal contamination than open area. So, not only the industrial activities but also traffic sources such as emission from automobiles, vehicles moving without fitness, activities of roadside artisans such as vehicle repairing, welding and uses or disposal of goods that contain metals contributed to the elevated level of metals. A highly significant correlation is observed between $\mathrm{Cr}-\mathrm{Fe}, \mathrm{Cr}-\mathrm{Co}, \mathrm{Cr}-\mathrm{Sc}, \mathrm{Fe}-\mathrm{Co}, \mathrm{Fe}-\mathrm{Sc}$, and $\mathrm{Co}-\mathrm{Sc}$.

\section{Acknowledgments}

The authors are grateful to the Reactor Operation and Maintenance group and staffs of the Reactor and Neutron Physics Division for their support to carry out this experiment.

\section{References}

Bowen, H.J.M. 1979. Environmental Chemistry of the Elements, 2nd Ed. New York Academic Press, New York.

Ehmann, W.D. and E.V. Diane. 1991. Radiochemistry and Nuclear Methods of Analysis, 1st Ed. WileyInterscience Publication, Canada.

Greenberg, R.R., P. Bode and E.A.D.N. Fernandes. 2011. Neutron activation analysis: a primary method of measurement. Spectrochimica Acta Part B: Atomic Spectroscopy 66(3-4): 193-241.

Harfouche, M., A.M. Ghrair, D.M.M. Jaradat, G. Aquilanti, R. Jaber, A. Aldrabee and N. Sawai. 2016. Absorption and mobility of $\mathrm{Cr}$ and $\mathrm{Zn}$ in soil in the vicinity of Jordan river. Journal of Physics: Conference Series 712(1): 012080.

Islam, M.A., S.A. Latif, S.M. Hossain, M.S. Uddin and J. Podder. 2011. The concentration and distribution of trace elements in coals and ashes of the Barapukuria thermal power plant, Bangladesh. Energy Sources, Part A: Recovery, Utilization, and Environmental Effects 33(5): 392-400.

Islam, M.A., A. Al-Mamun, F. Hossain, S.B. Quraishi, K. Naher, R. Khan, S. Das, U. Tamim, S.M. Hossain and F. Nahid. 2017. Contamination and ecological risk assessment of trace elements in sediments of the rivers of Sundarban mangrove forest, Bangladesh. Marine Pollution Bulletin 124(1): 356-366.

Kabata-Pendias, A. and H. Pendias. 2001. Trace Elements in Soil and Plants 3rd Ed. London, CRC press, Boka Raton.

Khademi, H., M. Gabarrón, A. Abbaspour, S. MartínezMartínez, A. Faz and J.A. Acosta. 2019. Environmental impact assessment of industrial activities on heavy metals distribution in street dust and soil. Chemosphere 217: 695-705.

Krishna, A.K. and P.K. Govil. 2004. Heavy metal contamination of soil around pali industrial area, Rajasthan, India. Environ Geology 47(1): 38-44.

Krishna, A.K. and P.K. Govil. 2007. Soil contamination due to heavy metals from an industrial area of Surat, Gujarat, Western India. Environmental Monitoring and Assessment 124: 263-275.

Kumar, V., A. Sharma, P. Kaur, G.P.S. Sidhu, A.S. Bali, R. Bhardwaj, A.K. Thukral and A. Cerda. 2019. Pollution assessment of heavy metals in soils of India and ecological risk assessment: A state-of-the-art. Chemosphere 216: 449-462.

Latif, S.A., D. Afroj, S.M. Hossain, M.S. Uddin, M.A. Islam, K. Begum, Y. Oura, M. Ebihara and M. Katada. 2009. Determination of toxic trace elements in foodstuffs, soils and sediments of Bangladesh using instrumental neutron activation analysis technique. Bulletin of Environmental Contamination and Toxicology 82: 384-388.

Lian, M., J. Wang, L. Sun, Z. Xu, J. Tang, J. Yan and X. Zeng. 2019. Profiles and potential health risks of heavy metals in soil and crops from the watershed of Xi River in Northeast China. Ecotoxicology and Environmental Safety 169: 442-448.

Li, P., C. Lin, H. Cheng, X. Duan and K. Lei. 2015. Contamination and health risks of soil heavy metals around a lead/zinc smelter in southwestern China. Ecotoxicology and Environmental Safety 113: 391-399.

Mandal, A. and D. Sengupta. 2006. An assessment of soil contamination due to heavy metals around a coal-fired thermal power plant in India. Environmental Geology 51: 409-420. 
Rudnick, R.L. and S. Gao. 2014. Composition of the Continental Crust. Treatise on Geochemistry, 2nd Ed. Elsevier Science, USA.

Salmons, W. and U. Frostner. 1995. Heavy Metals.1st Ed. Springer-Verlag, Berlin Heidelberg.

Sultana, M.S, Y. Muramatsu and S. Yoshida. 2003. Levels of lanthanides and natural radionuclides in the uncultivated soils near industrial area of Bangladesh. International Journal of Environmental Analytical Chemistry 83(5): 375-387.

Tamim, U., R. Khan, Y.N. Jolly, K. Fatema, S. Das, K. Naher, M.A. Islam, S.A. Islam and S.M. Hossain. 2016. Elemental distribution of metals in urban river sediments near an industrial effluent source. Chemosphere 155: 509-518.
Wu, Q., J.Y. Leung, X. Geng, S. Chen, X. Huang, H. Li, Z. Huang, L. Zhu, J. Chen and Y. Lu. 2015. Heavy metal contamination of soil and water in the vicinity of an abandoned e-waste recycling site: implications for dissemination of heavy metals. Science of the Total Environment 506: 217-225.

Yarlagadda, P.S. and M.R. Matsumoto. 1995. Characteristics of heavy metals in contaminated soils. Journal of Environmental Engineering 121(4): 276-286. 